\title{
PLTD Engine Tank Oil Volume Monitoring System using HC-SR04 Ultrasonic Sensor Based on Internet of Things (IoT)
}

\author{
Eko Prayetno* \\ Dept Of Electrical Engineering \\ Trisianto Nadapdap \\ Tanjungpinang, Kepulauan Riau Tanjungpinang, Kepulauan Riau \\ ekoprayetno@umrah.ac.id \\ trisiantonadapdap10@gmail.com \\ *corresponding author: eko prayetno, ekoprayetno@umrah.ac.id
}

\author{
Ani Sari Susanti \\ Dept Of Electrical Engineering \\ Tniversitas Maritim Raja Ali Haji
Tanjungpinang, Kepulauan Riau \\ anisarisusanti@gmail.com
}

\author{
Delta Miranda \\ Dept Of Electrical Engineering \\ Universitas Maritim Raja Ali Haji \\ Tanjungpinang, Kepulauan Riau \\ deltamiranda72@gmail.com
}

\begin{abstract}
The Diesel Power Plant is an oil-fired generator. The PLTD engine in Ranai uses Bio Solar fuel to produce $1 \mathrm{MW}$ of power. The PLTD engine in Ranai each has one tank with a capacity of 1820 liters. Within 1 hour of using a machine with a power of \pm , $750 \mathrm{KW}$ can consume \pm 182 liters of oil. The IoT system serves to simplify the work in the oil distribution system. This IoT system uses the ESP8266 as a microcontroller, the HCSR04 ultrasonic sensor as a volume level reader for the oil in the engine tank, and a relay as a replacement switch pump on or off. This tool works in real-time to help reduce the risk of negligence in refueling the engine. The Device testing results showed good results because the error value in the measurement distance test was $0 \%$. The tool can provide fast and accurate information because it is equipped with an information system using Android and notifications from email messages.
\end{abstract}

Keywords - Internet of Things, Microcontroller, Monitoring

\section{INTRODUCTION}

PT. PLN (Persero) ULP Natuna is a company engaged in the electricity sector, from operating power plants to transmitting to the public in Natuna Regency. The PT PLN (Persero) ULP Natuna generator system uses a diesel engine operated by PLTD Ranai. PT. PLN (Persero) ULP Natuna has nine operating machines where all the machines use Bio Solar fuel. The PLTD engine in Natuna is divided into two generator locations, namely in Ranai and Pian Tengah. The PLTD Ranai engine has 4 MTU engine units, each with $1 \mathrm{MW}$ (MegaWatt), and the Central Pian PLTD has 5 Cartepilar Engines with $1 \mathrm{MW}$ power. The PLTD engine that runs on bio-diesel uses an oil storage tank equipped with an oil filter engine. The oil entering the engine does not get dirty, which can interfere with the engine's ability to withstand customer loads. Each PLTD machine uses a tank with a capacity of 1820 liters. The PLTD machine operates for 24 hours, and every hour it can consume \pm 182 Liters/hour of oil. Currently, monitoring and measuring the oil level is still done manually.

The system for monitoring and measuring the oil level is still done manually, which causes the invalid data of the oil usage report, and there are frequent unnecessary blackouts due to human error and delays in the filling, turning on the pump to fill the oil into the tank. Therefore, to make it easier to monitor the oil level in the storage tank and prevent blackouts caused by human error, it is necessary to carry out technological innovations to monitor oil levels in real-time. The technology to be applied is to use the Internet of Things (IoT) using a smartphone as an interface with Blynk software as a liaison and an ultrasonic sensor to measure the oil used level.

Internet of Things (IoT) is an innovative technology used to collect, monitor, and analyze data in an integrated and realtime manner [1]. Internet of things (IoT) has promising capabilities to provide efficient data storage and exchange by connecting physical devices and the help of connecting platforms through electronic sensors and the internet [2]. Internet of Things (IoT) can be used as a visual analysis in providing information on water consumption so that humans can better understand and interact with data in real-time using the ubidots system [3]. Internet of Things (IoT) is also used as a gas station tank monitoring system to provide information that occurs in gas station storage tanks using Arduino Uno and ultrasonic sensors [4].

The Ultrasonic Sensor is used to measure the distance level. Ultrasonic sensors are used because they can measure distances straight from a predetermined object. Ultrasonic sensors can also help measure the level of liquid objects (oil and water) [5]. Here are some case studies of using ultrasonic sensors. The first is to make it easier to monitor the availability 
of diesel fuel in the generator engine tank due to its position in a place that is difficult to reach by humans; an ultrasonic ping sensor is used, which can be connected to Android to provide information on the height of the diesel tank with the help of the Application Programming Interface server [6]. In an automated non-intrusive control system for monitoring the water level of domestic overhead and underground reservoir tank base on wave reflection property using HC-SR04 Ultrasonic transceivers that generate ultrasonic pulses and determine the water surface's depth based on the total Time of Flight (TOF) of the reflected wave and ATMEGA328 microcontroller was programmed to read the sensors, control the water level, and display the water's corresponding volume on Display LCD [7]. Still about monitoring the diesel tank volume, but using ultrasonic (PING) sensors and PIC16F877A microcontroller and LCD display used to monitor diesel tanks' volume in real-time [8]. Another case study is about monitoring water level control using ultrasonic sensors, an ESP8266, and the information can be monitored directly from a PC [9]. In addition, there are also those who monitor water levels using ultrasonic sensors whose data is stored in the email in real-time [10].

Then the monitoring system can use a smartphone via Bluetooth media used in monitoring smart home energy consumption [11]. In research [12] discusses more the interface, namely using the blynk application interface, which is an open-source application. On the Blynk interface, there are several very user-friendly features, namely the power button, display of device data readings, display of sensor data readings, and device operating time.

Therefore, in this study, the application of Internet of Things (IoT) technology uses a smartphone as the interface with Blynk software and the HC-SR04 ultrasonic sensor. Blynk software functions as a control on the ESP8266 module and is used to connect a device that functions to display the distance value and oil volume, and the relay button. The HCSR0 ultrasonic sensor is an oil level gauge because it is quite efficient and also because it is easy to install, so it doesn't damage other components. By monitoring the tank's oil level using a smartphone, the user knows the notifications and indicators of the oil level in the tank in real time. After that, if the oil level has shown a low/empty or high/full level, we can control the oil pump using a smartphone.

\section{RESEARCH METHODOLOGY}

\section{A. Design Planning}

At the manufacturing stage of a design device, it is crucial in the manufacturing process, especially in this device with an internet-connected system; therefore, it is necessary to pay attention to every electronic component and application used in this system. At this stage, there are three stages of the design, namely System Planning. The design of monitoring the volume of the PLTD engine oil tank consists of several primary devices, namely ultrasonic sensors HC-SR04as input, ESP8266 as the data processor, relay, oil pump, and smartphone as output. The picture shows that the HC-SR04 ultrasonic sensor detects the oil level in the engine tank; if the sensor detects oil in LOW conditions, the ESP8266 gives a notification to the smartphone via the blink application, then the user sends a command to the ESP8266 using a cellphone to order the relay to become NC (Normally Closed) relay as a replacement contact for the oil pump. If the sensor detects that the oil level has been detected HIGH, the ESP8266 orders the relay to be NO (Normal Open) to turn off the oil pump.

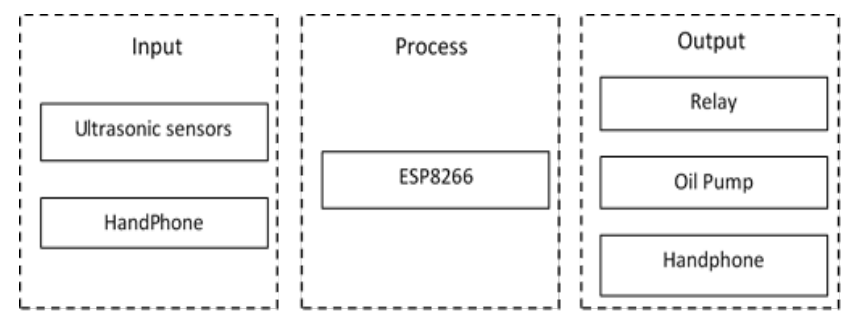

Fig. 1. System Planning

The HC-SR04 ultrasonic sensor inputs the distance data to the oil which then the sensor data will be forwarded to Arduino Uno to process the data. The HC-SR04 ultrasonic sensor data will be processed through the $\mathrm{C}$ program language on the Arduino Uno software by writing the sensor command to detect that the oil level is a distance value and the volume of liters this information to Android using the Blynk application. Suppose the user has seen that the oil level condition is LOW. In that case, the user will press the ON button on Blynk to command the ESP8266 to make the relay in NC (Normally Closed) condition, which turns on the oil pump as well as the full oil level condition, then press the OFF button to make the relay in NO conditions (Normally Open).

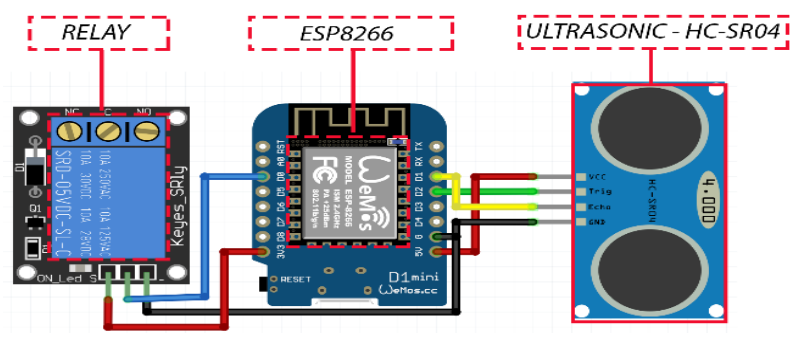

Fig. 2. Wiring Electrical Device

In the wiring design, the device uses an ultrasonic sensor HC-SR04, ESP8266, and relays. ESP8266 instructs ultrasonic relays and sensors HC-SR04 to execute and execute commands from the device. The design uses the HC-SR04 ultrasonic sensor to detect the engine tank's oil volume and the relay as a replacement switch to turn on or turn off the oil pump. In wiring design, the relay functions as a switch to activate and deactivate control devices. The relay circuit is connected to pins D0 and D5. To activate the relay, connect VCC and Ground to the ESP8266.

There are four oil tanks in the PLTD. The capacity of each tank is the same, namely $100 \times 18.2=1820$ Liters. Each tank will be installed with an IoT (Internet of Things) Device that will be integrated with smartphones. The fixing device is designed permanently on each tank. Each tank is also equipped with an HC-SR04 ultrasonic sensor, which functions as a reader for the volume of oil in the PLTD tank. This tool works in real-time to help reduce the risk of negligence in refueling the engine. The device is also added to a relay that 
functions as an automatic switch so that the process of turning off and starting the pump can be done remotely.

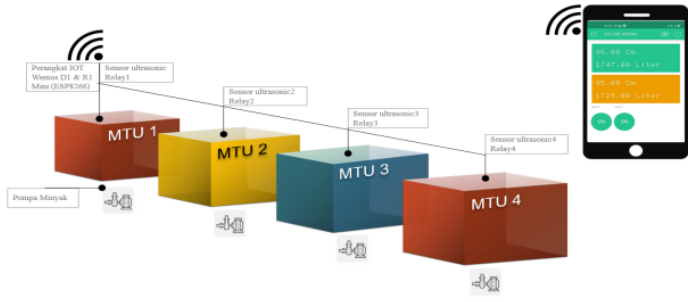

Fig. 3. Mechanical Design

The distance between one tank and another is 3 meters so that monitoring devices can be installed on each tank at close range. The use of smartphones in tool design also helps in the process of monitoring oil levels. It can control and know the oil level remotely and can be accessed anywhere, provided that you have internet access. The software used in reading and receiving data is through the Blynk software, which can be downloaded through the Playstore and Appstore.

\section{B. The Device Works}

This Device works are using an ultrasonic sensor to detect the oil tank and the Blynk application to monitor the volume of oil. The IoT system serves to simplify the work in the oil distribution system. This IoT system uses the ESP8266 as a microcontroller, the HC-SR04 ultrasonic sensor as a volume level reader for the oil in the engine tank, and a relay as a replacement switch off the oil pump.

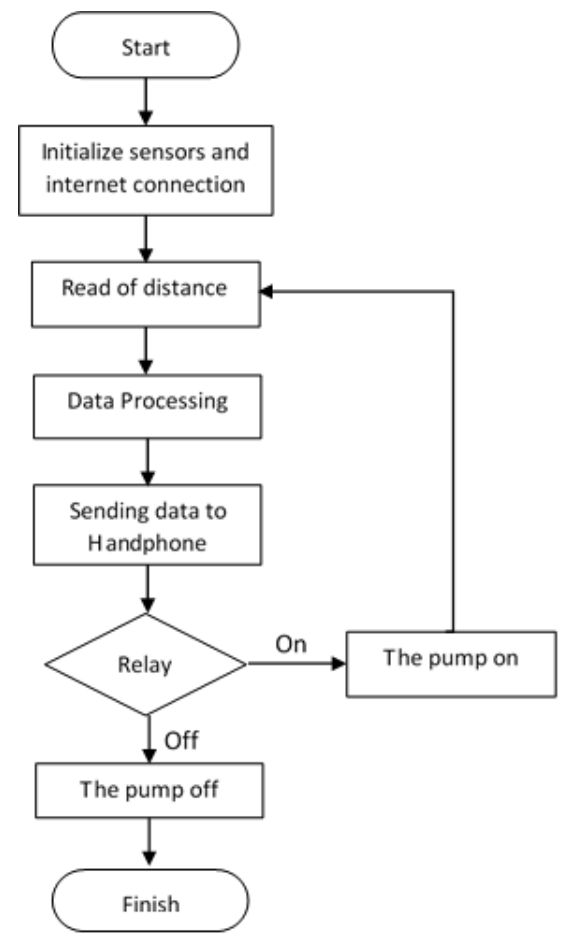

Fig. 4. How the Device Works

The Device works start with initializing the HC-SR04 ultrasonic sensor and then connecting to the internet via the Blynk application. The HC-SR04 ultrasonic sensor's function is to read the distance between the surface and the oil volume; after the sensor reads the volume of oil in the tank, the value is sent to the Blynk application that has been installed on the smartphone. To turn on or turn off the switch can also be done via a smartphone by setting the relay installed on the test device. If the relay is ON, the pump will start, and the relay will send a Return command with a distance reading made by the HC-SR04 ultrasonic sensor. If the sensor is in OFF condition, the pump will stop, and the process of sending data and information is complete.

\section{RESULT AND DISCUSSION}

\section{A. Testing and Analysis}

Testing the ESP8266 Wemos D1 Mini to find out each digital port of the ESP8266 Wemos D1 Mini is functioning correctly, the researchers conducted tests on the digital pin port, which is on the device design.

TABLE 1. DIGITAL PORT TESTING

\begin{tabular}{|c|c|c|}
\hline PIN & $\begin{array}{c}\text { HIGH } \\
\text { (Voltage VDC) }\end{array}$ & $\begin{array}{c}\text { LOW } \\
\text { (Voltage VDC) }\end{array}$ \\
\hline D0 & 3.31 & 0.05 \\
\hline D1 & 3.31 & 0.00005 \\
\hline D2 & 3.31 & 0.0005 \\
\hline D3 & 3.31 & 0.21 \\
\hline D4 & 3.31 & 0.05 \\
\hline D5 & 3.31 & 0.0005 \\
\hline
\end{tabular}

In testing the ESP8266 Wemos DI Mini, testing was carried out on a digital pin. The pins tested are pins D0, D1, D2, D3, D4, and D5. The testing process is carried out by entering the High Voltage and Low Voltage voltages. At High Voltage, the maximum measurement for the ESP8266 pin is 3.7 Volt DC. The test results follow the desired voltage to operate the electronic module or device in the design system. Whereas at Low Voltage or when the tool is not operating (not ordered), the voltage is obtained with the results in Table 1. Thus, the monitoring device will not work because the measured voltage is as large as shown in Table 1.

\section{B. Ultrasonic Sensor HC-SR04 Testing}

Testing of the HC-SR04 ultrasonic sensor to determine the accuracy of the distance detects any reduction or addition of oil in the engine tank and ensures that the sensor has been calibrated.

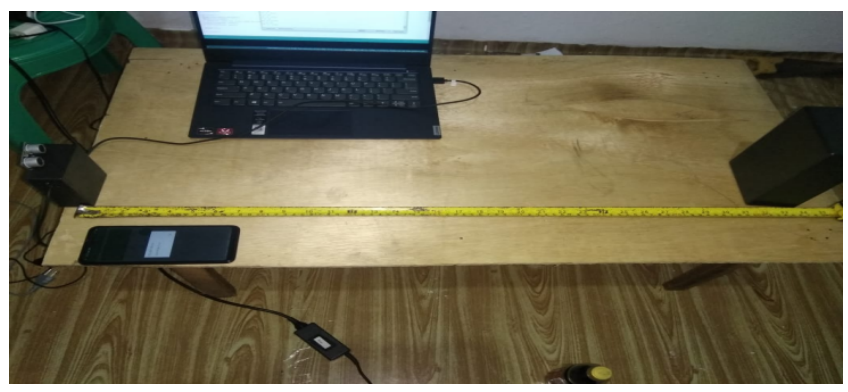

Fig. 5. Ultrasonic Sensor Calibration 
Testing the HC-SR04 ultrasonic sensor on the test, there are ten levels detecting distance, namely when the oil level is 0 $\mathrm{cm}$ to $100 \mathrm{~cm}$ where every $10 \mathrm{~cm}$ changes the sensor is tested. The results are obtained every $10 \mathrm{~cm}$ of testing from the ultrasonic sensor calibration to get different results. The higher the sensor distance at the oil level, the higher the sensor reading.

TABLE 2. ULTRASONIC SENSOR TESTING

\begin{tabular}{|c|c|c|}
\hline Distance (Cm) & Sensor (CM & Error (\%) \\
\hline 10 & 10 & 0 \\
\hline 20 & 20 & 0 \\
\hline 30 & 30 & 0 \\
\hline 40 & 40 & 0 \\
\hline 50 & 50 & 0 \\
\hline 60 & 60 & 0 \\
\hline 70 & 70 & 0 \\
\hline 80 & 80 & 0 \\
\hline 90 & 90 & 0 \\
\hline 100 & 100 & 0 \\
\hline
\end{tabular}

Table 2 shows the distance $(\mathrm{cm})$, the sensor reading value $(\mathrm{cm})$, the difference between the distance and the sensor readings, and the error value obtained. On the difference, the result is 0 for each distance reading. The error value obtained for each reading distance is $0 \%$. The value of $0 \%$ is because there is no difference in the sensor reading value and the test distance.

\section{Relay Testing}

This test uses a two-channel relay module to determine whether the relay used can function properly seen in its resistance value. Relays are measured on the relay coil and contacts NO (Normally Open) and NC (Normally Closed) when activated or deactivated using a multimeter measuring instrument. The coil relay test results are shown in Table 3.

TABLE 3. RELAY TESTING

\begin{tabular}{|c|c|}
\hline Relay Testing & Relay 1 \\
\hline Normally Open & $\infty$ \\
\hline Normally Closed & $0 \Omega$ \\
\hline Resistance Coil & $69 \Omega$ \\
\hline
\end{tabular}

In the Relay test, the results are normally Open, which is when the relay is not energized, you get the result (infinity), which indicates that when the relay is not powered, the design device will not work or will not read the test data. Next is the Normally Close test, namely, relay testing so that the oil monitoring device can work and read data. The monitoring device used in the oil monitoring design that utilizes a relay as an automatic switch uses the Blynk application; thus, the relay test data is shown in Table 3.

\section{Blynk Application Testing}

Blynk is software that functions as a control on the ESP8266 module. For application, testing consists of 4 stages. The first is the addition of a new project, the second is the auth token, which addresses that the device is connected to the Blynk. The third is an LCD widget that functions to display the value of distance and oil volume, and then the fourth widget button is for the relay button. Testing the Blynk application aims to ensure that the device is connected to the internet and read by the Blynk application. In this test, it can be seen in the figure that the device can connect to the internet and is read by the Blynk application.

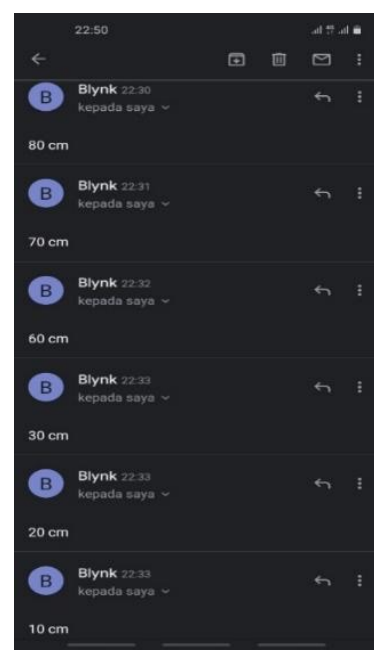

Fig. 6. Blynk Application Testing

In testing the oil level reading using the Blynk application, each reading result is found in table 4 . As the test sample, in Figure 6 is the data from the sensor readings at a distance of $71 \mathrm{~cm}$, the results are 162.66 liters, and 60 results are 137.46 liters. Testing this application at every distance of $90,80,70$, $60,50,40,30,20$, and $10 \mathrm{~cm}$ will show a notification to Android and send an email message.

\section{E. Discussion}

The PLTD Engine Tank Oil Volume Monitoring work system Using Internet Of Things (IoT) Based Ultrasonic Sensors is when the device is connected to an adapter and then connected to the internet network. The sensor will start detecting the oil level in the engine tank.
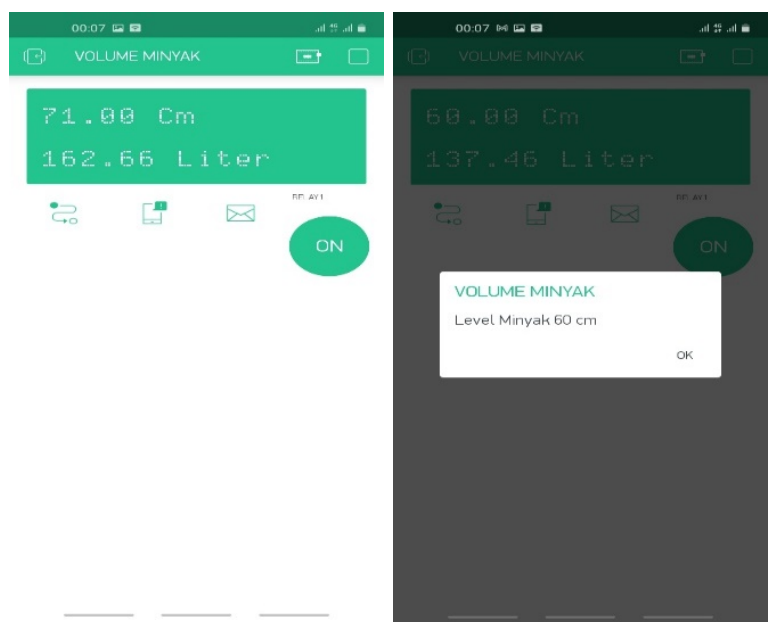

Fig. 7. Testing Devices 
Testing on the Device uses a distance measuring device using a meter measuring tool as a calibration as well as measuring the accuracy of the device against direct measurement using a meter measuring device as shown in Figure 7, for this tank size, namely the tank height $90 \mathrm{~cm}$, radius $27 \mathrm{~cm}$, the volume of the tank namely $206202,85 \mathrm{~cm} 3$. Therefore, the volume of the tank is 206,20285 liters. Each $1 \mathrm{~cm}$ represents 2,291 Liters or $2292 \mathrm{~cm} 3$. Device testing is done by determining a certain distance using an ultrasonic sensor. For more details, the results of testing the device are in Table 4.

TABLE 4. DEVICE TESTING RESULTS

\begin{tabular}{|c|c|c|c|}
\hline Distance (Cm) & Sensor (CM & Volume (L) & Error (\%) \\
\hline 10 & 90 & 206.19 & 0 \\
\hline 20 & 70 & 160.37 & 0 \\
\hline 30 & 60 & 137.46 & 0 \\
\hline 40 & 50 & 114.55 & 0 \\
\hline 50 & 40 & 91.64 & 0 \\
\hline 60 & 30 & 68.73 & 0 \\
\hline 70 & 20 & 45.82 & 0 \\
\hline 80 & 10 & 22.91 & 0 \\
\hline 90 & 0 & 0 & 0 \\
\hline
\end{tabular}

From Table 4 it can be seen the results of the system test. That is, every $10 \mathrm{~cm}$ of testing using an ultrasonic sensor, the reading is on the Blynk. Every $10 \mathrm{~cm}$, the lower the oil level, the lower the ultrasonic sensor reading distance. This is because the ultrasonic sensor functions as an oil level reading.

In testing the device's working system, it can be seen in table 4 that the test results of the device take data every $10 \mathrm{~cm}$ change. It can be seen that the sensor detects and the device can provide this data in the Blynk application and calculates the calculation of the oil volume according to the conditions in the tank, where the tank has a height of $90 \mathrm{~cm}$. Every $1 \mathrm{~cm}$ in the tank contains 2,291 liters. In this data, it can be seen that every $10 \mathrm{~cm}$ change in volume decreases because the sensor is placed at the top of the tank. The calculation is done by subtracting the tank's height from a distance detected to the oil so that the farther the distance detected, the smaller the oil level and the smaller it is the volume of oil.

\section{CONCLUSION}

Monitoring the volume of the engine oil tank using an ultrasonic sensor based on the internet of things is a system that works in real-time so that it can help reduce the risk of negligence in refueling the PLTD contained in PT. PLN (Persero) ULP Natuna for the power plant. The devices used in the design process are divided into two, namely software design and hardware design. For software design, the author uses Blynk software and Arduino programming as controls.
Simultaneously, the hardware design consists of a control module ESP8266, which functions as a control module, an ultrasonic sensor, as a data reader for the tank's oil level. And the relay functions as an automatic switch to turn on and off the pump. This device's design is simulated using a water tank, and this simulation is successful and very good to be applied to the oil tank monitoring system at PLTD Ranai.

\section{ACKNOWLEDGMENT}

The researchers would like to thank God Almighty for the blessings and gifts the researchers received to complete this article. Thank you also to the Department of Electrical Engineering, Faculty of Engineering, Raja Ali Haji Maritime University.

\section{REFERENCES}

[1] Mohammad Salah Uddin Chowdury, "IoT Based Real-time River Water Quality Monitoring System", Procedia Computer Science, pp: 161-168, 2019.

[2] Sharmad Pasha, "Thingspeak Based Sensing and Monitoring System for IoT with Matlab Analysis", International Journal of New Technology and Research (IJNTR), Volume 2, Issue 6, pp: 19-23, 2016.

[3] Aldrin C. Tasonga, Roland P. Abao, "Design and Development of an IoT Application with Visual Analytics for Water Consumption Monitoring", Procedia Computer Science, pp: 205-213, 2019.

[4] Sorongan, A., Hidayanti, Q., Priyono, K., "ThingSpeak Sebagai Sistem Monitoring Tangki SPBU Berbasis Internet Of Things", JTERA Jurnal Teknologi Rekayasa, Vol. 3, No. 2, pp: 219-224, 2018.

[5] Pratama, N., "Perancangan Sistem Monitoring Ketinggian Air Sebagai Pendeteksi Banjir Berbasis IoT Menggunakan Sensor Ultrasonik", Jurnal Media Informatika Budidarma, Vol. 4, No.2, 2020.

[6] Rony, M.A., Irawan, "Aplikasi Monitoring Volume Tangki Solar Menggunakan Sensor Ping Ultrasonik Berbasis Android”, Prosiding SENDI, 2019.

[7] M. I. Bello, 2018. "Autonomous Ultrasonic Based Water Level Detection and Control System", Nigerian Journal of Technology (NIJOTECH), Vol. 37, No. 2, pp: 508-513, 2018.

[8] Saleem Latteef Mohammed, "Highly Accurate Water Level Measurement System Using a Microcontroller and an Ultrasonic Sensor", IOP Conf. Series: Materials Science and Engineering, 2019.

[9] Ma'ruf, I., Hadi, A, "Monitoring kontrol level air menggunakan sensor ultrasonik berbasis PC", Seminar Nasional Industri dan Teknologi (SNIT), Politeknik Negeri Bengkalis, 2019.

[10] Amin, Ahmadil, "Monitoring Water Level Control Berbasis Arduino UNO Menggunakan LCD LM016L”, Jurnal EEICT, Vol. 1, No. 41, 2018.

[11] Yusnita Rahayu and Muhammad Ibnu Hidaya, "Bluetooth Based Home Control and Real-Time Energy Consumption Monitoring System through Smartphone", International Journal of Electrical, Energy and Power System Engineering (IJEEPSE), Vol. 2, No. 3, pp: 5-9, 2019.

[12] Rizki, M, "Perancangan Kontrol dan Monitoring Level Ketinggian Air di Waduk Bagian Hulu Untuk Meningkatkan Efektifitas Kinerja PLTA Kota Panjang", Jurnal FTEKNIK, Vol. 3, No. 1, 2016. 